\title{
STUDENTS' PERCEPTION ON THE USED OF LIQUID CRYSTAL DISPLAY (LCD) PROJECTOR IN ENGLISH FOREIGN LANGUAGE (EFL) CLASSROOM
}

\author{
Zahratul Idami \\ IAIN Langsa \\ zahratul21idami@gmail.com
}

\section{ABSTRACT}

In line with information and communication technology development, foreign-language teachers should prepare more exciting ways to enhance students' motivation in learning foreign language. One of the innovative media is Liquid Crystal Display (LCD) projector. Thus this article aims to find out and to describe students' perception on Liquid Crystal Display (LCD) projector in learning English Foreign Language (EFL). This research conducted for the second year students of SMA Negeri 1 Bireuen in academic year 2018/2019 with total population 331 students and 90 of them were the sample. This was a qualitative descriptive research, and questionnaire was used as the instrument to obtain the data. Moreover, the simple calculation of descriptive statistics was used in analyzing the data, such as mean and percentage. The result revealed that the availability of Liquid Crystal Display (LCD) projector in EFL classroom built a more conducive and vivid learning atmosphere, so the students' motivation was also improved.

Keywords:

Students' perception, Liquid Crystal Display (LCD) Projector, English Foreign Language (EFL) Classroom

\section{INTRODUCTION}

In Indonesia, although English is one of the compulsory subjects, it is still considered as a foreign language. However, English is really needed in 
almost every sector of society lives, particularly in the sectors of business, politics, education and the media. It has an important role to connect people and make them easier in communicating (Lauder, 2010). Furthermore, English is the subject which is taught since elementary school up to university level. It shows that English is an important subject to be learnt.

Nowadays, realizing the essential of English mastery forces teachers to find and create innovative ways and media in teaching English Foreign Language (EFL). With the development of technology and the digital revolution, EFL teachers should be more attractive in determining teaching materials and media which are in accordance with the demand of the curriculum. This is necessary for improving students' enthusiasm and willingness to learn foreign language. Likewise the English teachers at SMA Negeri 1 Bireuen, one of the most favorite state senior high school in Bireuen regency, the teachers should improve their skills in teaching, not only the knowledge and material but also they should enrich the teaching media by utilizing technology invention in order to empower ideal teaching and learning atmosphere in the classroom. Most of English teachers at that school have already been using technological devices such as laptop and Liquid Crystal Display (LCD) projector in teaching. Hopefully this may help students to make improvement with English. Besides, Kirkpatrick (2007) as cited from Sulistyo (2016) claims that there was no any precious improvement of English teaching and learning process in Indonesian schools and colleges. However, recently, many education practitioners keep trying to develop the quality of education in Indonesia. One of the efforts includes the use of digital media to improve teaching and learning process. Furthermore, every step in improving education quality should keep the students interested in gaining new knowledge. Thus, this research seems to figure out the 
perception of the students toward the use of Liquid Crystal Display (LCD) projector as a media in learning English.

In line with the explanation above, there are several studies that had been conducted about the similar issue. Some scholars from Indonesia and abroad who have investigated the perception of the students' toward the used of multimedia as a media to motivate students in learning. Firstly, Amine (2012) conducted a research under the title Using Multimedia to Motivate Students in EFL Classroom: A Case Study of English Master's Students at Jijel University, Algeria. This study prepared questionnaire for specific purpose which was administered to 120 students who were studying at master degree at Med Seddik Benyahia University, Algeria. The students were the first-year students and the second-year students from the same field of English studies. The findings of the research showed that both levels of students believed that the technology used in their EFL classroom might motivate them and increase their motivation in learning EFL. Additionally, the students thought that the material teachers downloaded from the internet sometimes was ineffective, however, the used of multimedia technology in learning EFL could make the class more enjoyable and avoided boring lecture.

Next, a research by Dalita (2015) about the students' perception toward Liquid Crystal Display (LCD) projector in learning English was conducted at a public vocational school in Padang, West Sumatra, Indonesia. Interview protocol was administered for the second year students of SMK 5 Padang for collecting the data in this phenomenological research. From the result of the interview, it was found that the students had positive perception toward the use of LCD projector because of three reasons; interesting, efficiency, and effectiveness. 
In addition, Aina (2013) also conducted a qualitative phenomenological research in West Sumatra, Indonesia about students' perception on a media as an instructional technology used by the lecturers in teaching English at STKIP PGRI. In this research, the researcher used interview which conducted individually with the determined correspondent. The interview showed that the students agreed with the used of instructional technology such as laptop and Liquid Crystal Display (LCD) projector as media in learning English. On the other hand, there was some students did not agree with the used of those media in classroom due to some reasons such as the using of the media made some students sleepy, bored, and ignored the lesson.

In short, in accordance with the explanation and description above, the writer would like to conduct a research discussing about the perception of the students toward such the media used by the teachers for teaching English, entitled the Students' Perception on the Used of Liquid Crystal Display (LCD) Projector in English Foreign Language (EFL) Classroom.

\section{LITERATURE REVIEW}

In EFL teaching and learning, identifying the perception of the students is important to help teachers to determine and improve their teaching. Those include the students' perception on the strategy used by the teachers, the assessment, and also the media that the teachers use to deliver the material. Wood (2009) states that the perception is the process of selecting, organizing, and interpreting an object to product information about it. Individuals see and feel the objects. Then they will get some information and knowledge about them. The information about the object then will be interpreted in the brain, so the individual can get an image of the object. This 
opinion will be different from one individual and others. Furthermore, Aque (2007) says that perception is such a process to understand the object becomes a mediated experience, and in the process, it requires the senses to process the data. In addition, he also defines perception as what the body can be able to perceive, and to be perceivable, the object must be understood by the mind through the interaction of sight, sound, taste, touch and smell. An impression then must pass through the body through one of sensory organ, that is, the eye, ear, nose, mouth, or skin in order to be perceived. Then the perceptions will emerge as the consequence of those sensations. The body will interpret those perceivable things. Hence, when teachers use Liquid Crystal Display (LCD) projector as a medium in teaching, then the students will perceive the medium whether they may enjoy it or not.

\section{Liquid Crystal Display (LCD) Projector}

Liquid Crystal Display (LCD) projector is not a new invention. It is found in 1968 in New York by Gene Dolgoff. In 1988, Dolgoff began working in Project Vision Inc, when the first time Liquid Crystal Display (LCD) projector was established. In the beginning, when LCD did not have its own light source yet, it is used with the presented systems on the overhead projector. After trying many various materials, Dolgoff finally got a perfect idea to establish the world's earliest liquid crystal display (LCD). By giving great endeavor eventually, LCD projector then can be successful and well known to this day. Furthermore, Law (2014) states that the technology of LCD projector is started initially with the use of back part of projection television consoles, LCD projection system was tried in many various sizes of televisions and it showed better image quality to a 60 -inch television, 
although this time LG 100 inch LCD TV has produced as the main rival of the technology.

In the context of teaching, various media forms in Liquid Crystal Display (LCD) projector such as text, animation, picture, video, and graphic can assist the teacher to deliver the lesson material to the students. Thus hopefully, the used of LCD projector as a medium in teaching can also make students enjoy and be more interested in acquiring the new knowledge.

According to Jarrett (2017), putting educational technology frontage and centre in classroom is one technique to obtain the students' interest. Moreover, he claims that the use of LCD projector may improve the learning experience of the students and it is able to expand the teachers' teaching talent. In other words, it can be said that there are a lot of advantages of using LCD projector in the classroom as follows:

- It is easy to use LCD projector since the writing and erasing can be done instantly by a quick click so the lesson and information can be conveyed easily to the students.

- Instead of focused on the teachers, students will be more focused on the lesson presented on the display. That will help them to understand the lesson more quickly.

- Teachers do not have to rely on printed materials since a projector will help them to explain any materials such as chart, maps, and graphs in detail.

- It can help the teachers and students to give a better analyze and clarify about the materials presented by using slide demonstrations. It is believed that the slide can assist the students to understand the materials easier.

- A click can be used to present the repeating information in back few slides asked by the students, thus it can share and update everything efficiently. 
- LCD projector is fun and entertaining medium for the students because they not only can learn through the display but also they can show and tell their presentations through the projector and they will enjoy it.

On the other hand, Mott (2001) states that LCD projector also has weaknesses because it will limit the presentation of teachers' material since it shows only what the teachers write or place on the display. Finding enough room then will be a challenge for using LCD projector especially in small space with hard-to-move furniture and weighty equipment. Besides, its high temperature can also be a quandary.

\section{RESEARCH METODOLOGY}

This reasearch uses a descriptive study as the design. According to Ary and Sorensen (2006), descriptive study is a study which focuses on the description of social phenomenon. This study mainly focuses on the perception of the students toward the used of Liquid Crystal Display (LCD) projector as the main media in English Foreign Language (EFL) classroom. The total sample for this research was 90 students who were studying at State Senior High School 1 Bireuen. Furthermore, the writer used the questionnaire in order to gain the data. There are 10 points that the writer discussed in this study. Those 10 points showed the students' perception on the Liquid Crystal Display (LCD) projector as the media in learning English. Then to analyze the data, the writer used the descriptive statistical formula to calculate the percentage and the findings would be described in detailed.

\section{FINDINGS AND DISCUSSIONS}

Students' perception on the used of Liquid Crystal Display (LCD) projector in EFL classroom will be described in the following explanations. 
First of all, the description shows the used of LCD projector in EFL classroom are quiet frequent. $91,11 \%$ or 82 students agreed about that. However, 2,22\% or 2 students were not sure and 6 students or $6,67 \%$ were disagreed. Meanwhile, according to the students, LCD projector as a media in learning EFL was interesting enough since $86,67 \%$ of the students felt more enjoyable in learning English. Besides, there were 5,56\% of the students were not sure about their perception and the last $7,78 \%$ or 7 students said that they did not enjoy the class. The explanations will be shown in the following figures.

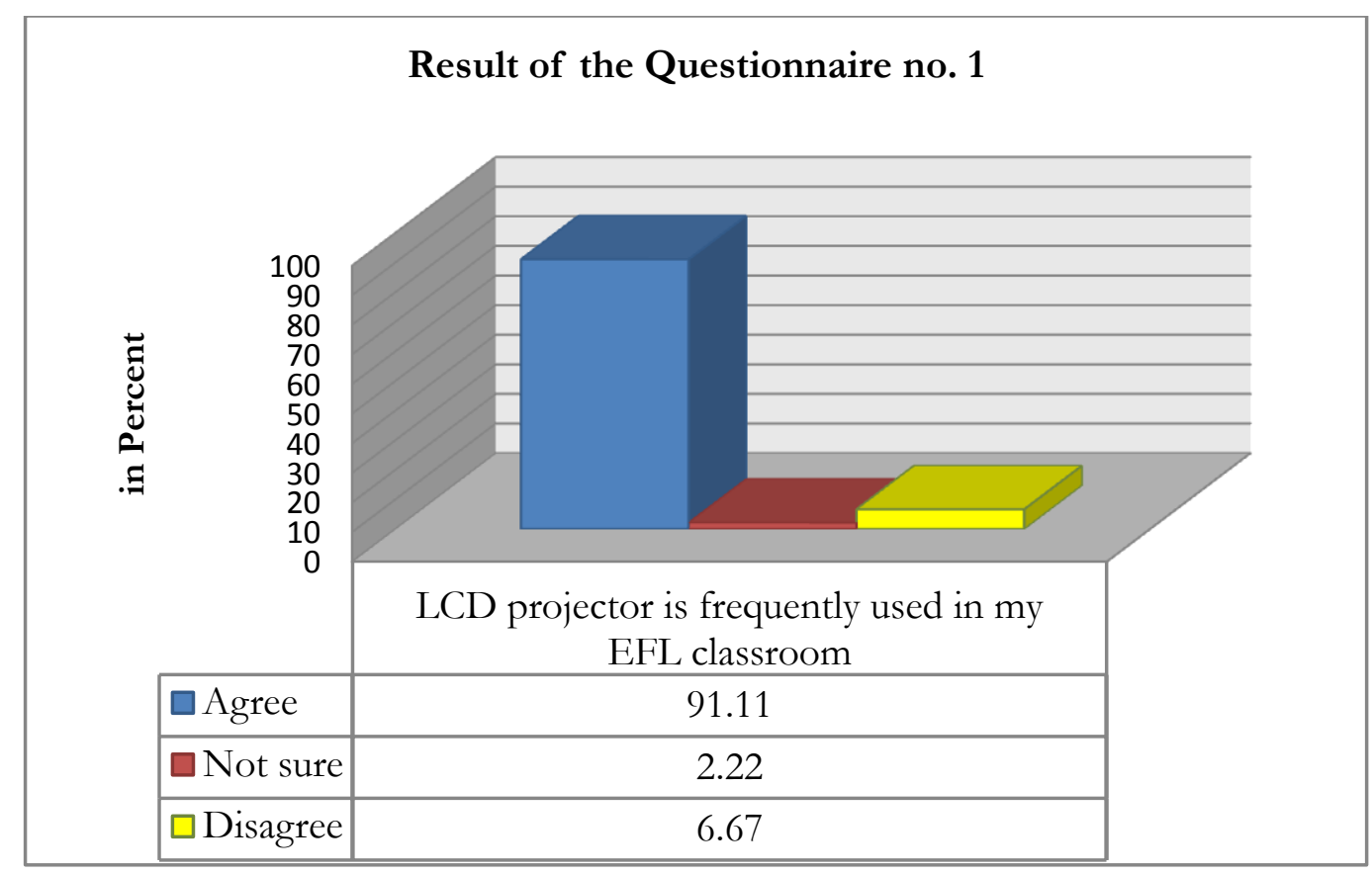

Figure 1 


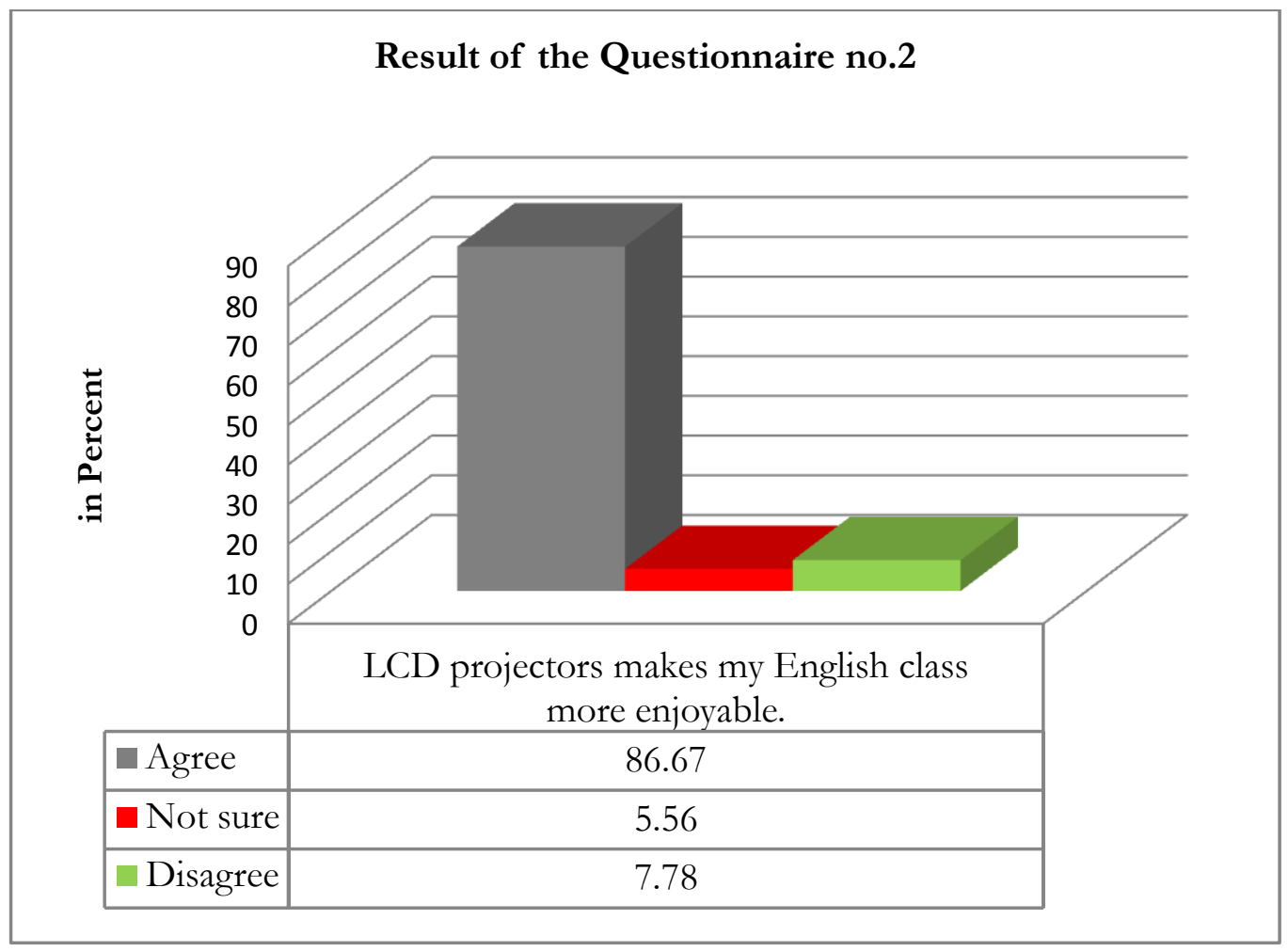

Figure 2

Third, the perception of the students was about the advantage of the use of LCD projector to make the students easier in understanding the teacher's explanation. There were $78,8 \%$ or 71 students could understand the material easier when the teacher used LCD projector. On the other hand, there were 10 students felt unsure about that and there were 9 students or $10 \%$ did not feel easier in understanding the teacher's explanation. That can be seen in this figure. 


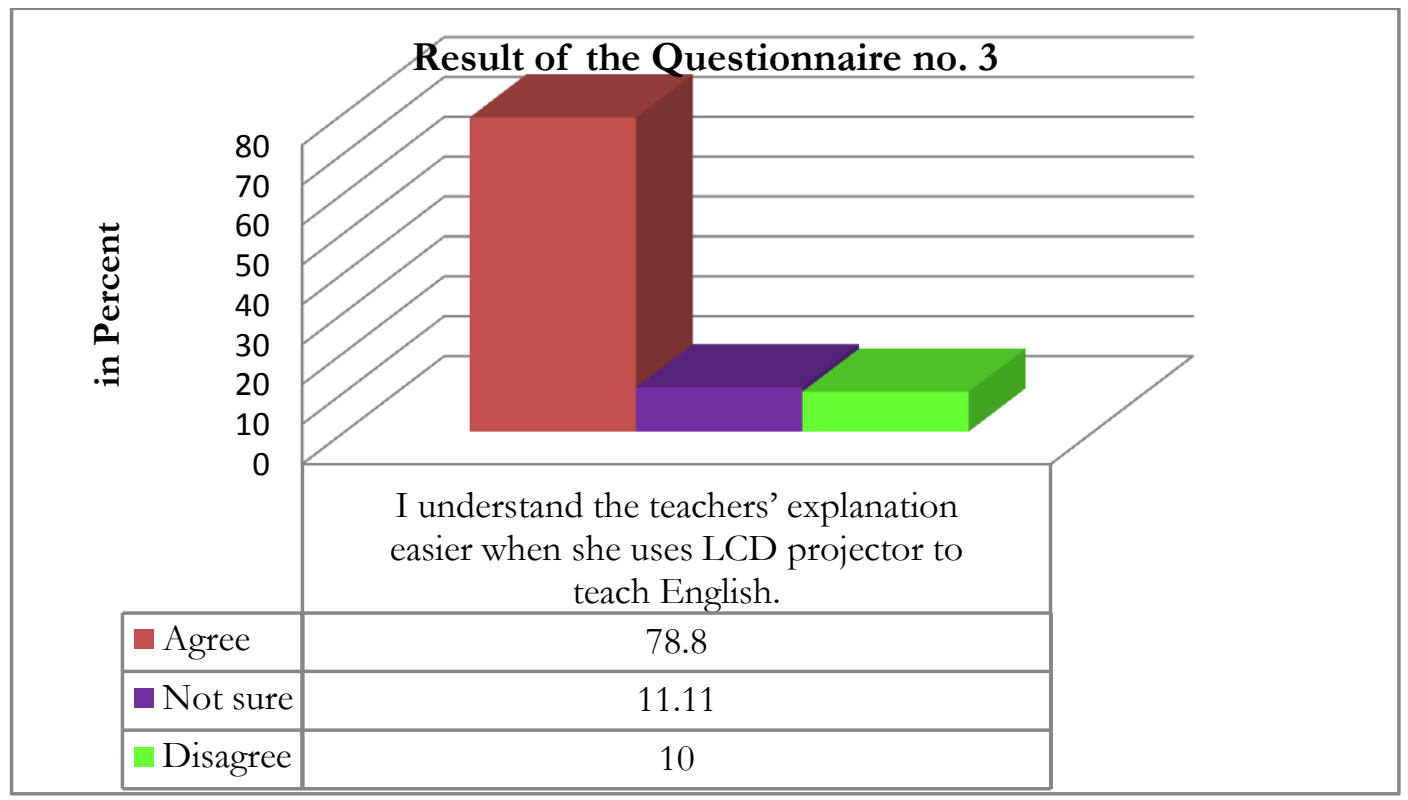

Figure 3

Next, power points, videos, films, pictures those ere presented through LCD projector, according to $72,2 \%$ of the correspondense or 65 students, were able to assist them to increase their speaking skills. On the contrary, it was $10 \%$ or 9 students were not sure and $17,78 \%$ or 16 students had different opinion about it. The following figure will show the concise description. 


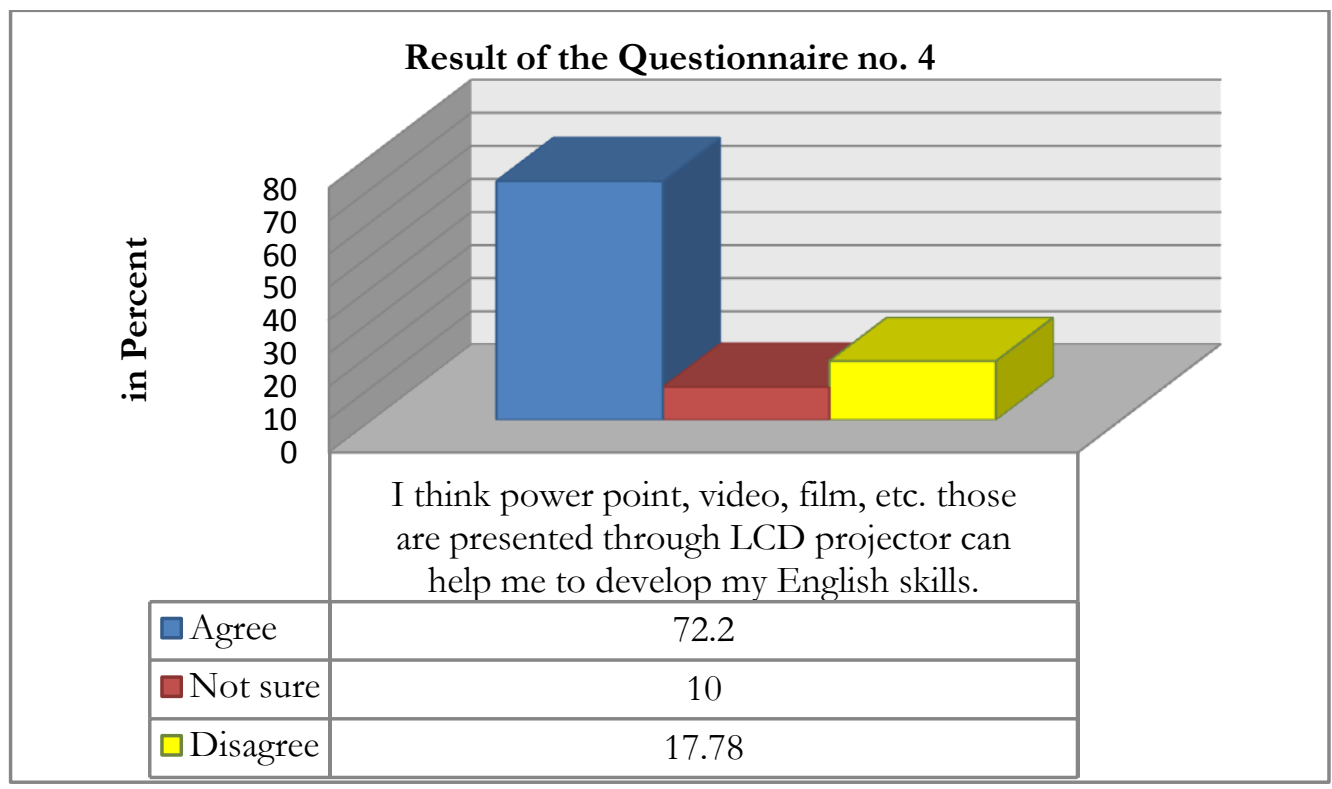

Figure 4

Furthermore, there were $70 \%$ or 63 students thought learning English by using LCD projector was more interesting rather than learning English through other media. Meanwhile, 18,89\% or 17 students were not sure about the statement and $11,11 \%$ or 10 students disagreed. In addition, $65,56 \%$ or 59 students said that LCD projector could make them be more active while learning EFL, but $7,78 \%$ or 7 students mentioned that they were nor sure and $26,67 \%$ or 24 students claimed that LCD projector could not make them be more active in learning English. The descriptions can be shown by the following figures. 


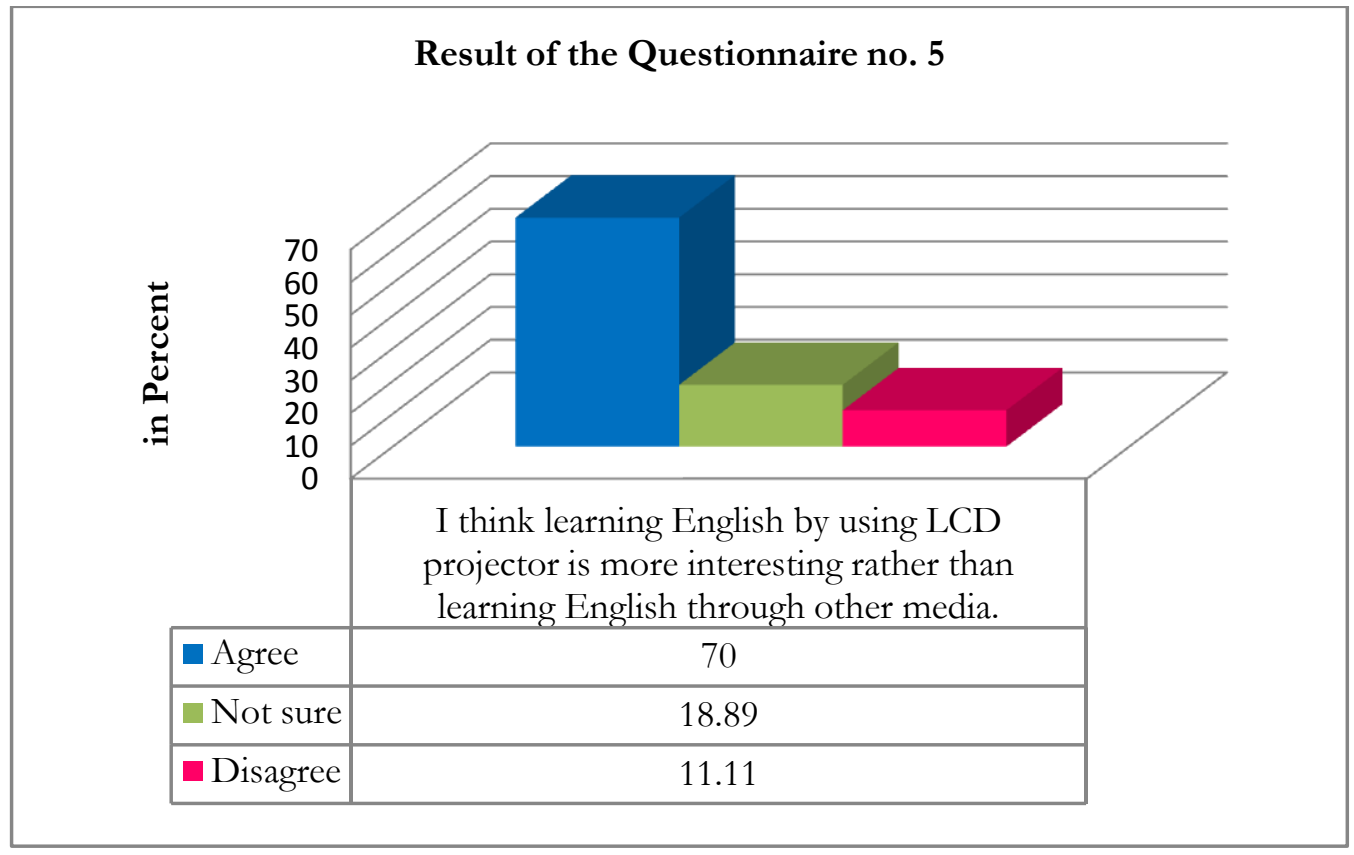

\section{Figure 5}

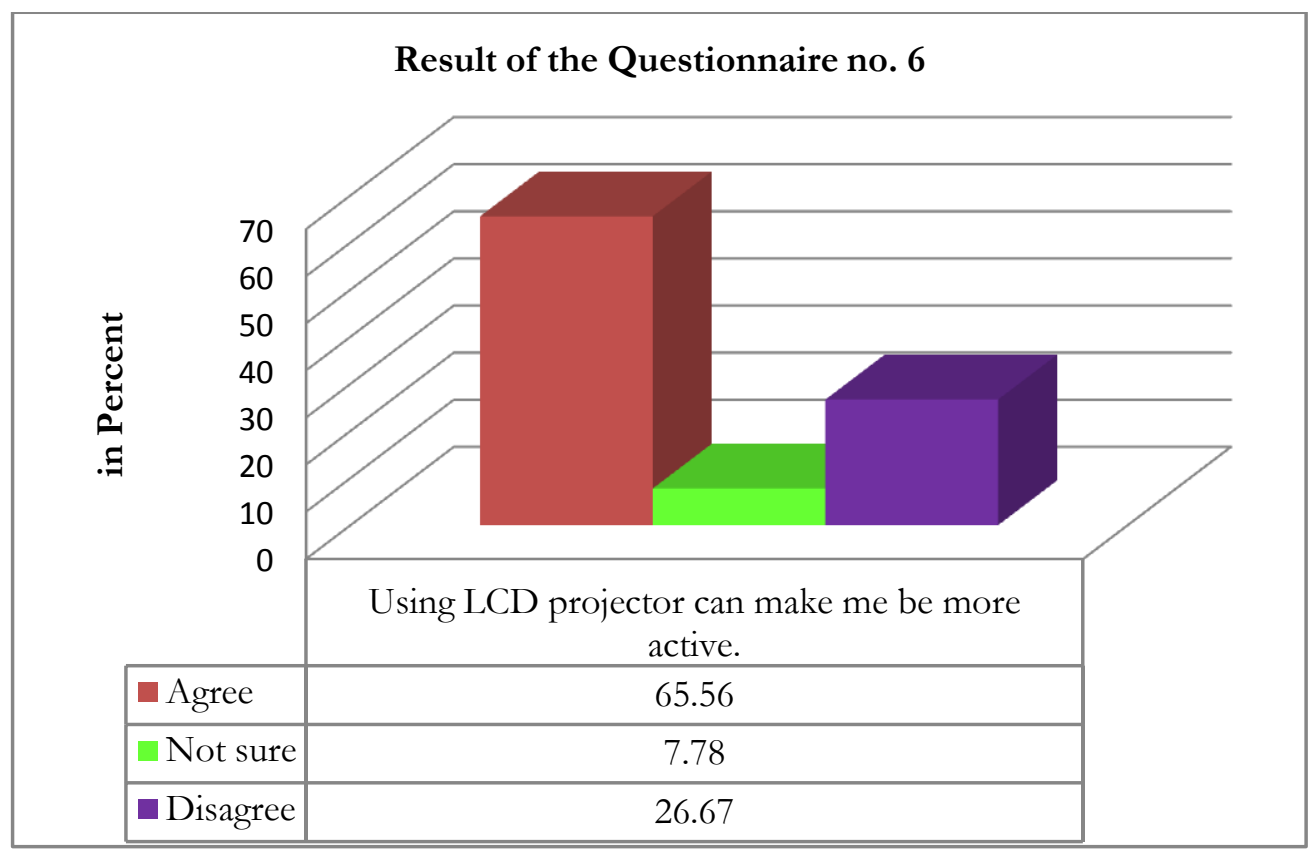

Figure 6 
As can be seen from the figure below, there were $73,33 \%$ or 66 students agreed if the teacher used LCD projector in every English classroom. Besides, there were $15,56 \%$ or 14 students were not sure about that and $11,11 \%$ or 10 students disagreed if the teacher used the LCD projector as the media in every English classroom.

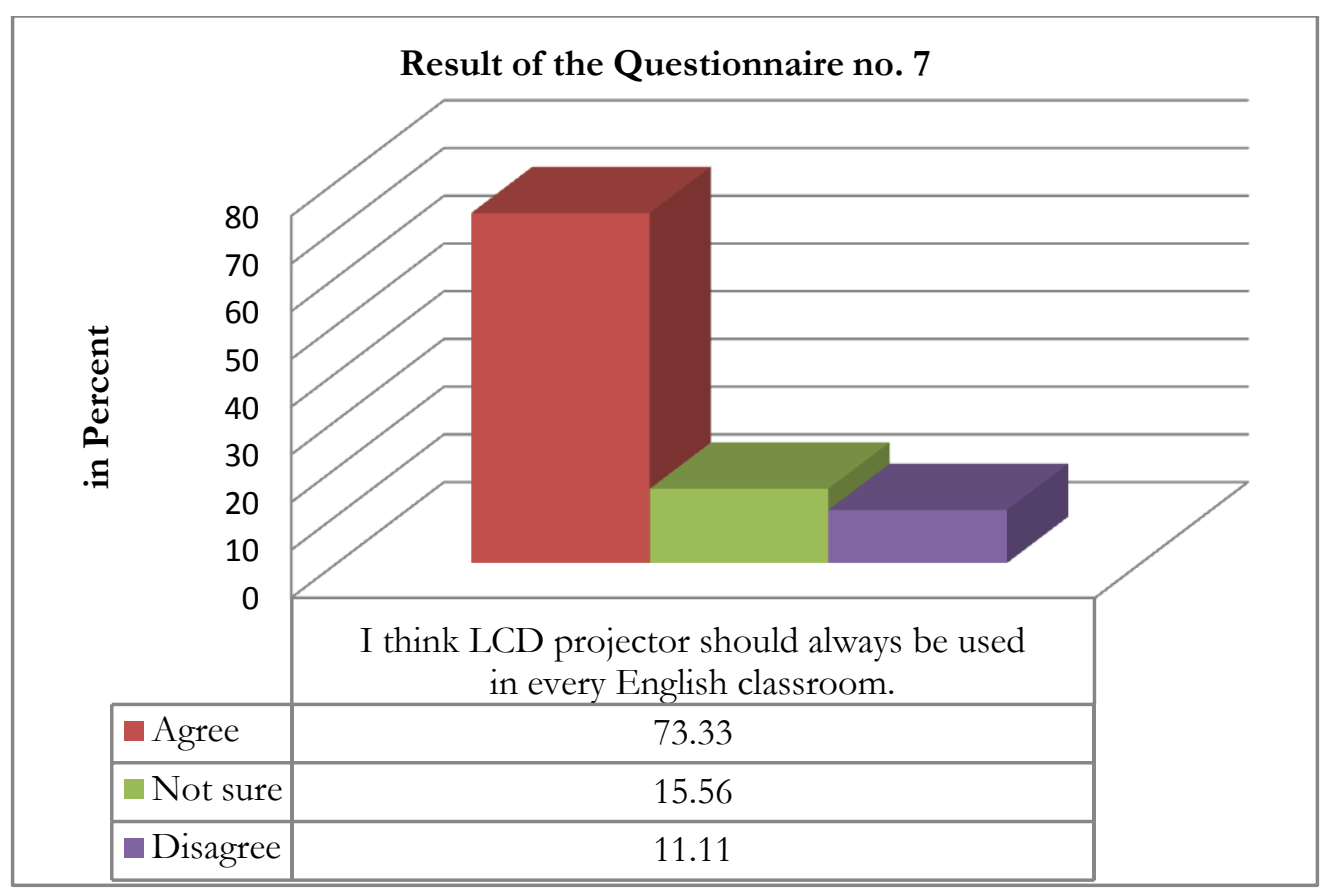

Figure 7

In the following figure, we may find that there were $86,67 \%$ or 78 students stated that using LCD projector could make English class more effective than traditional ways in teaching, but $8,89 \%$ or 8 students were still doubt and $11,11 \%$ of the students disagreed with the idea. 


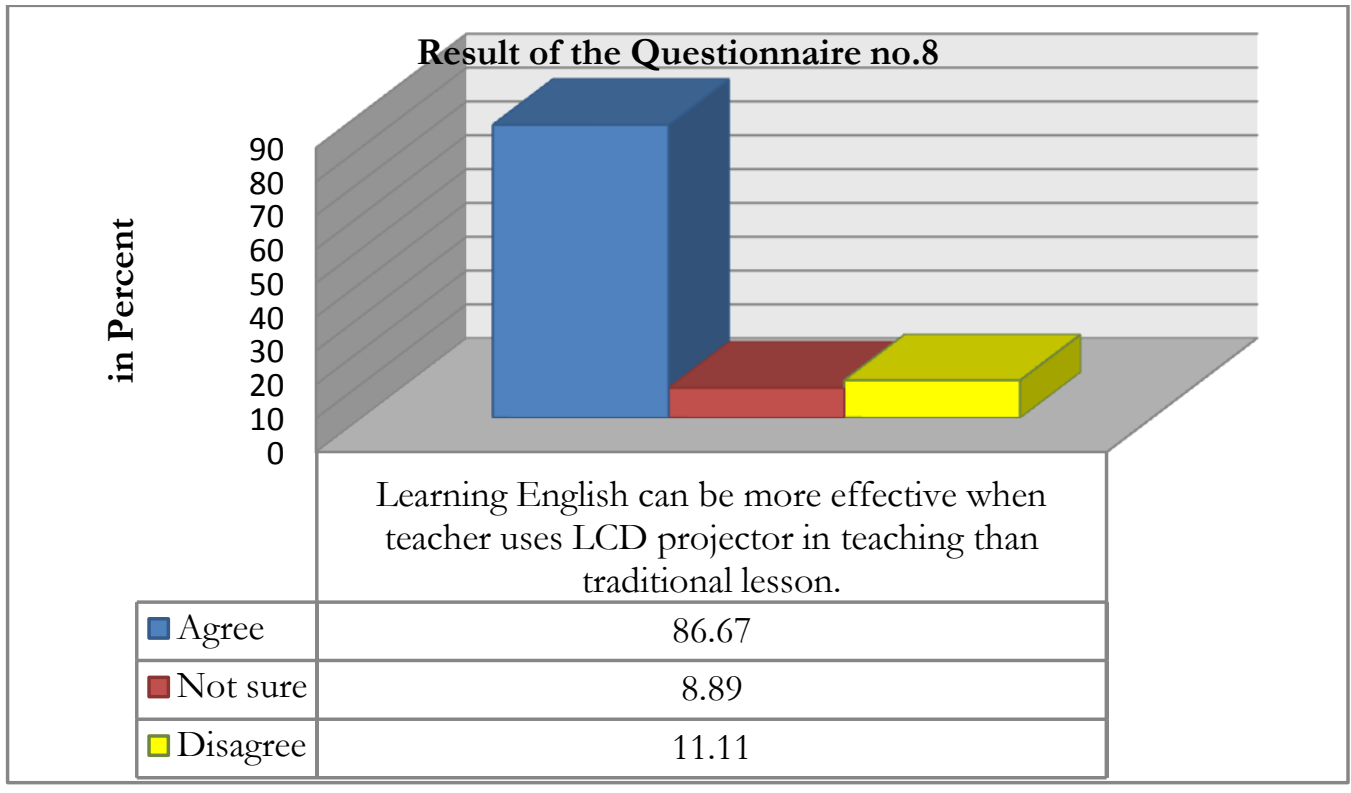

Figure 8

Moreover, according to $72,22 \%$ or 65 students agreed if LCD projector gave the motivation to learn English. Meanwhile, $20 \%$ or 18 students were doubt and $7,78 \%$ or 7 students thought that they were not motivated by the use of LCD projector. Then there were $64,44 \%$ or 58 students were agreed if LCD projector was used in every lesson as the media, but $27,78 \%$ or 25 students were still not sure about that and there were $7,78 \%$ or 7 students thought that it would be a bad idea if every lesson had LCD projector as the media in learning. These following figures would show a brief description about the explanation. 
Journal of Linguistics, Literature \& Language Teaching

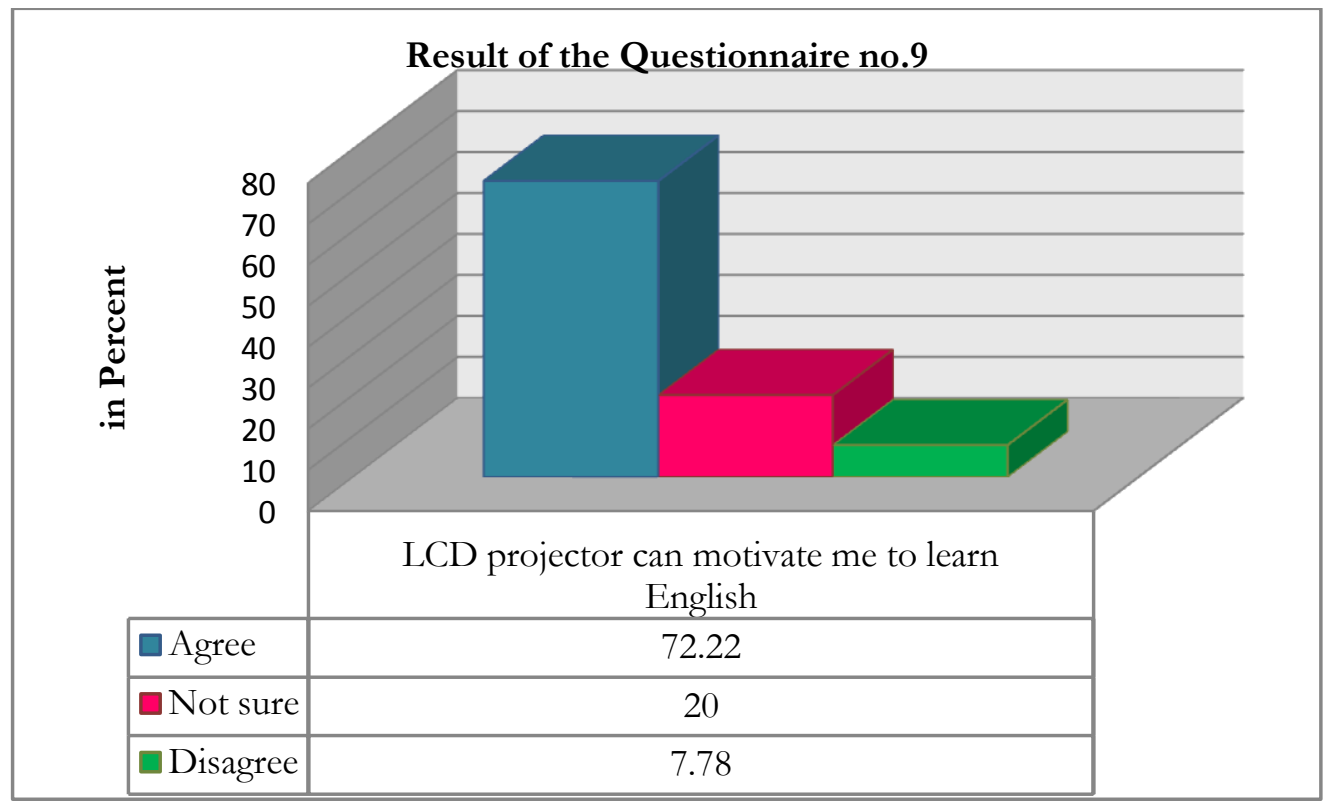

Figure 9

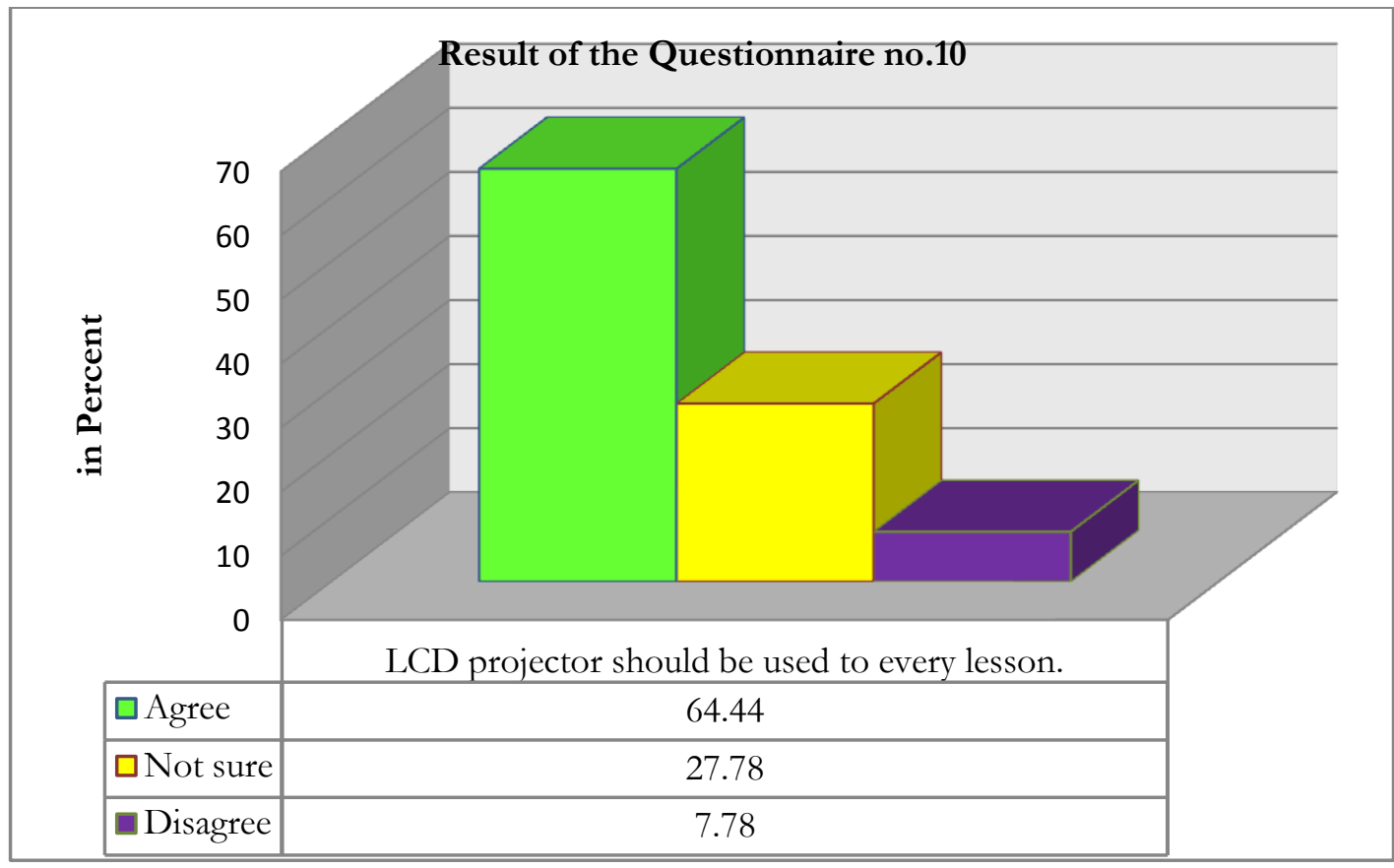

Figure 10 


\section{CONCLUSION AND SUGGESTION}

Based on the data analyzed and described on the previous chapter, it is showed that there are some students who disagree to the used of Liquid Crystal Display (LCD) projector as the media in learning English. However, when the teacher uses Liquid Crystal Display (LCD) projector, most of them are motivated and interested in learning English. Furthermore, the data also described that there are a large number of students whose perception toward the used of Liquid Crystal Display (LCD) projector in learning English is positive due to its effectiveness in empowering their understanding. Only a few numbers of the correspondents feel dissatisfied with the used of Liquid Crystal Display (LCD) projector in English Foreign Language (EFL) classroom.

For the suggestions, it is important to keep recognizing the students' perception on the media used by the teacher in the classroom in order to avoid the trouble in delivering the material and to build such a good atmosphere to learn in the classroom. These are believed can help students to develop their enthusiasm and motivation to learn. Thus the used of suitable media in teaching is crucial for the teachers to be applied.

\section{REFERENCES}

Aina, N., Riny, S., \& Sevrika, H. (2016). An Analysis of Students' Perception on Media as An Instructional Technology Used by Lecturers in Teaching English at STKIP PGRI West Sumatera. Jurnal Ilmiah Mabasiswa STKIP PGRI Sumatera Barat, 17(68), 12-13.

Amine, B. M., Benachaiba, C., \& Guemide. (2012). Using Multimedia to Motivate Students in EFL Classroom: A Case Study of English Master's Students at Jijel University, Algeria. Malaysian Journal of Distance Education, 14(2), 63-81. 
Aque, C. (2007). Perception. Theories of Media. The Chicago School of Media Theory.

Retrieved http://csmt.uchicago.edu/glossary2004/perceptionperceivability.ht $\mathrm{m}$

Dalita, R., Imelwaty, S., \& Kemal, E. (2015). Students' Perception toward LCD Projector in Learning English at the Classroom. Jurnal Ilmiah Mahasiswa STKIP PGRI Sumatera Barat, 13(55), 10-14.

Jarett, N. (2017). 20 Ways Projectors Improve Learning in the Classroom. Edtech 4 Beginners. Retrieved from https://edtech4beginners.com/2017/06/13/20-ways-projectorsimprove-learning-in-the-classroom/

Kirkpatrick, A. (2007). World Englishes: Implications for International Communication and English Language Teaching. London: Cambridge University Press.

Lauder, A. (2010). The status and function of English in Indonesia: a review of key factors. Hubs-Asia, 9(2).

Law, A. (2014). LCD Projector History. English Shared. Retrieved from http://teaching-direction.blogspot.com/2014/06/lcd-proyectorhistory.html

Mott, E. (2014). What are the Disadventages of Using an Overhead Projector? Azcentral Part of the USA Today Network. Retrieved from https://yourbusiness.azcentral.com/disadvantages-using-overheadprojector-1614.html

Wood, J.T. (2009). Communication in Our Lives ( $7^{\text {th }}$ ed). Chapel Hill.: University of North Carolina. 